\title{
KESIAPAN PRODI PENDIDIKAN SEJARAH DALAM MENGHADAPI TANTANGAN REVOLUSI INDUSTRI 4.0
}

\author{
Rusdi \\ Email: rusdi64@fis.unp.ac.id \\ Dosen Prodi Pendidikan Sejarah Universitas Negeri Padang
}

\begin{abstract}
Abstrak
Perubahan dunia kini tengah memasuki era revolusi industri 4.0 atau revolusi industri dunia keempat dimana teknologi informasi telah menjadi basis dalam kehidupan manusia. Segala hal menjadi tanpa batas (borderless) dengan penggunaan daya komputasi dan data yang tidak terbatas (unlimited), karena dipengaruhi oleh perkembangan internet dan teknologi digital yang masif sebagai tulang punggung pergerakan dan konektivitas manusia dan mesin. Era ini juga akan mendisrupsi berbagai aktivitas manusia, termasuk di dalamnya bidang ilmu pengetahuan dan teknologi (iptek) serta pendidikan tinggi. Revolusi industri 4.0 secara umum diketahui sebagai perubahan cara kerja yang menitikberatkan pada pengelolaan data, sistem kerja industri melalui kemajuan teknologi, komunikasi dan peningkatan efisiensi kerja yang berkaitan dengan interaksi manusia. Data menjadi kebutuhan utama organisasi dalam proses pengambilan keputusan korporat yang didukung oleh daya komputasi dan sistem penyimpanan data yang tidak terbatas. Lalu, bagaimana pengaruh Revolusi Industri 4.0 bagi Perguruan Tinggi saat ini khsusnya bagi Prodi Pendidikan Sejarah? Arus globalisasi ini sudah tidak terbendung masuk ke Indonesia. Disertai dengan perkembangan teknologi yang semakin canggih, dunia kini memasuki era revolusi industri 4.0, yakni menekankan pada pola digital economy, artificial intelligence, big data, robotic, dan lain sebagainya atau dikenal dengan fenomena disruptive innovation. Menghadapi tantangan tersebut, pengajaran di perguruan tinggi pun dituntut untuk berubah, termasuk dalam Pembelajaran Pendidikan Sejarah.
\end{abstract}

Kata Kunci: Pendidikan Sejarah, Perguruan Tinggi, Revolusi Industri 4.0

\section{Pendahuluan}

Saat ini dunia sudah masuk pada Era Industri 4.0, atau dikenal juga revolusi digital dan era disrupsi teknologi. Di segala sektor, isu perubahan pada Era Industri 4.0 banyak dibicarakan. Hal ini menggambarkan, betapa Era Industri 4.0 bukan hal yang bisa dipandang sebelah mata, namun harus disikapi dengan bijak dan cerdas oleh semua kalangan, khususnya perguruan tinggi, agar tidak tergilas oleh arus perubahan yang begitu dahsyat. Di Indonesia, era industri 4.0 sudah diterapkan dan sangat terasa pengaruhnya di masyarakat. Segala macam kegiatan sudah dinyatakan dalam bentuk digitalisasi. Tengok saja di bidang transportasi, muncul bisnis berbasis Internet, yaitu dengan munculnya perusahaan Grab dan Gojek. Transaksi keuangan berbasis digital sudah merupakan hal umum dilakukan, dimana kostumer tidak perlu antre lagi di depan kasir sebuah bank, namun cukup meng-click ponselnya dimanapun dan kapanpun, maka 
transaksi langsung dieksekusi. Orang berbelanja barang, makanan, atau keperluan lainnya cukup pula meng-click ponselnya. Pembayaran biaya jalan toll cukup dengan kartu elektronik, tanpa perlu operator. Bahkan, di beberapa gerbang toll, pembayaran terjadi secara otomatis begitu mobil melewati sensor di gerbang toll, tanpa perlu si pengemudi menempelkan kartu elektroniknya ke alat pembaca kartu. Dampaknya, banyak toko tradisional, dimana pedagang dan konsumen bertemu untuk melakukan transaksi secara langsung mulai sepi/ pengunjungnya berkurang, taksi dan ojek tradisional tergerus oleh taksi dan ojek on-line.

Arus globalisasi ini sudah tidak terbendung masuk ke Indonesia. Disertai dengan perkembangan teknologi yang semakin canggih, dunia kini memasuki era revolusi industri 4.0, yakni menekankan pada pola digital economy, artificial intelligence, big data, robotic, dan lain sebagainya atau dikenal dengan fenomena disruptive innovation. Menghadapi tantangan tersebut, pengajaran di perguruan tinggi pun dituntut untuk berubah, termasuk dalam Pembelajaran di Prodi Pendidikan Sejarah.

\section{Metodologi}

Definisi Era Industri dimulai dari sejarah revolusi industri yang dijelaskan oleh Lee et al (2013), Herman et al (2016) dan Irianto (2017) dalam Yahya (2018). Angka 1.0, 2.0, 3.0, dan saat ini 4.0, merupakan penanda awal perubahan yang terjadi sepanjang masa industrialisasi diperkenalkan. Era revolusi industri merupakan vase perubahan nyata yang terjadi di dunia industri yang tidak mengenal batas wilayah. Era industri 1.0 adalah era dimana diperkenalkannya mekanisasi dalam dunia industri sehingga aktivitas manusia menjadi lebih efektif dan efisien. Era ini dilanjutkan dengan Era Industri 2.0 dimana pada saat itu dimulai diperkenalkannya produksi masal dan diterapkannya standardisasi mutu. Pengenalan proses industri berbasis otomasi dan robot merupakan pananda dimulainya Era industri 3.0. Pada saat ini, dikenal dengan era industri 4.0, merupakan masa dimana penggunaan cyber yang dikolaborasi dengan manufaktur banyak diterapkan. Hal ini ditunjukkan dengan adanya peningkatan volume data, kekuatan komputasi dan konektivitas, munculnya analisis, kemampuan, dan kecerdasan bisnis; terjadinya bentuk interaksi baru antara manusia dengan mesin; dan perbaikan instruksi transfer digital ke dunia fisik, seperti robotika dan 3D printing. https://www.its.ac.id/news/2018/11/04/35759/ 
Klaus Schwab dalam bukunya The Fourth Industrial Revolution (2016) mengemukakan tentang Revolusi Industri Generasi Keempat (Revolusi Industri 4.0) yang ditandai dengan kelahiran artificial intelegent pada ragam bentukan produk yang dapat bekerja layaknya fungsi otak manusia yang dioptimalisasikan. Otomasi dan pengambilalihan bidang kerja yang dimekanisasi melalui perangkat digital menjadi keniscayaan dan mengarahkan pada praktikpraktik bidang kerja yang berpusat pada eliminasi 'berkedok' efisiensi tenaga kerja manusia sebagai muaranya. Ragam 'kecerdasan buatan' tersebut di antaranya adalah super komputer, robot pintar, kendaraan tanpa pengemudi, dan lain sebagainya. Konsep Revolusi Industri 4.0 ini menemukan pola dan mekanisme kerja baru ketika disruptif teknologi hadir begitu cepat yang secara bertahap mendominasi sendi kehidupan dan keseharian manusia. (https://kumparan.com/birokrat-menulis/mengurai-pekerjaan-rumah-pendidikan-indonesiamenyongsong-revolusi-industri-4-0-1543639076398)

Perkembangan ilmu pengetahuan dan teknologi telah mengubah dunia sebagaimana revolusi industri generasi pertama melahirkan sejarah ketika tenaga manusia dan hewan digantikan oleh kemunculan mesin uap pada abad ke-18. Revolusi ini dicatat oleh sejarah berhasil mengangkat naik perekonomian secara dramatis. Berikutnya, pada revolusi industri generasi kedua ditandai dengan kemunculan pembangkit tenaga listrik yang memicu kemunculan pesawat telepon, mobil, pesawat terbang, dan lainnya yang mengubah wajah dunia secara signifikan. Kemudian, revolusi industri generasi ketiga ditandai dengan kemunculan teknologi komputer, internet dan digital yang tidak saja mengubah dunia industri namun juga budaya dan habit generasi secara mendasar. Distruptif teknologi Revolusi industri generasi keempat ini ditandai dengan kemunculan komputer super, kecerdasan buatan atau Intelegensi Artifisial. "Akan banyak pekerjaan hilang digantikan dengan robot atau kecerdasan buatan. Namun juga menjadi peluang karena banyak bidang pekerjaan baru yang muncul. (https://edukasi.kompas.com/read/2018/05/02/15561621/ki-hadjar-dewantara-dan-guncanganpendidikan-era-industri-40)

Revolusi industri 4.0 secara umum diketahui sebagai perubahan cara kerja yang menitikberatkan pada pengelolaan data, sistem kerja industri melalui kemajuan teknologi, komunikasi dan peningkatan efisiensi kerja yang berkaitan dengan interaksi manusia. Data menjadi kebutuhan utama organisasi dalam proses pengambilan keputusan korporat yang didukung oleh daya komputasi dan sistem penyimpanan data yang tidak terbatas. 


\section{Hasil dan Pembahasan}

\section{Tantangan Perguruan Tinggi menghadapi Revolusi Industri 4.0}

Menteri Riset, Teknologi, dan Pendidikan Tinggi (Menristekdikti) Mohamad Nasir menjelaskan, berdasarkan evaluasi awal tentang kesiapan negara dalam menghadapi revolusi industri 4.0 Indonesia diperkirakan sebagai negara dengan potensi tinggi. Meski masih di bawah Singapura, di tingkat Asia Tenggara posisi Indonesia cukup diperhitungkan. Sedangkan terkait dengan global competitiveness index pada World Economic Forum 2017-2018, Indonesia menempati posisi ke-36, naik lima peringkat dari tahun sebelumnya posisi ke-41 dari 137 negara. "Tetapi jika dibandingkan dengan Malaysia, Singapura, dan Thailand, kita masih di bawah. Tahun 2018 global competitiveness index Thailand di peringkat 32, Malaysia 23, dan Singapura ketiga. Beberapa penyebab Indonesia masih kalah ini karena lemahnya higher education and training, science and technology readiness, dan innovation and business sophistication. Inilah yang perlu diperbaiki supaya daya saing kita tidak rendah," tutur Nasir dalam konferensi pers di Gedung D Kemenristekdikti, Jakarta, Senin (29/1/2018)(http://sumberdaya.ristekdikti.go.id/index.php/2018/01/30/era-revolusi-industri-4-0saatnya-generasi-millennial-menjadi-dosen-masa-depan/)

Perguruan Tinggi merupakan lembaga formal yang diharapkan dapat melahirkan tenaga kerja kompeten yang siap menghadapi industri kerja yang kian berkembang seiring dengan kemajuan teknologi. Keahlian kerja, kemampuan beradaptasi dan pola pikir yang dinamis menjadi tantangan bagi sumber daya manusia, di mana selayaknya dapat diperoleh saat mengenyam pendidikan formal di Perguruan Tinggi.

Kuantitas bukan lagi menjadi indikator utama bagi suatu perguruan tinggi dalam mencapai kesuksesan, melainkan kualitas lulusannya. Kesuksesan sebuah negara dalam menghadapi revolusi industri 4.0 erat kaitannya dengan inovasi yang diciptakan oleh sumber daya yang berkualitas, sehingga Perguruan Tinggi wajib dapat menjawab tantangan untuk menghadapi kemajuan teknologi dan persaingan dunia kerja di era globalisasi.

Dalam menciptakan sumber daya yang inovatif dan adaptif terhadap teknologi, diperlukan penyesuaian sarana dan prasarana pembelajaran dalam hal teknologi informasi, internet, analisis big data dan komputerisasi. Perguruan tinggi yang menyediakan infrastruktur pembelajaran tersebut diharapkan mampu menghasilkan lulusan yang terampil dalam aspek 
literasi data, literasi teknologi dan literasi manusia. Terobosan inovasi akan berujung pada peningkatan produktivitas industri dan melahirkan perusahaan pemula berbasis teknologi, seperti yang banyak bermunculan di Indonesia saat ini.

Tantangan berikutnya adalah rekonstruksi kurikulum pendidikan tinggi yang responsif terhadap revolusi industri juga diperlukan, seperti desain ulang kurikulum dengan pendekatan human digital dan keahlian berbasis digital. Menteri Riset, Teknologi dan Pendidikan Tinggi M. Nasir mengatakan, "Sistem perkuliahan berbasis teknologi informasi nantinya diharapkan menjadi solusi bagi anak bangsa di pelosok daerah untuk menjangkau pendidikan tinggi yang berkualitas. "

Persiapan dalam menghasilkan lulusan yang mampu beradaptasi dengan Revolusi Industri 4.0 adalah salah satu cara yang dapat dilakukan Perguruan Tinggi untuk meningkatkan daya saing terhadap kompetitor dan daya tarik bagi calon mahasiswa. Berbagai tantangan sudah hadir di depan mata, sudah siap kah Perguruan Tinggi menyiapkan generasi penerus bangsa di era Revolusi Industri 4.0 dan persaingan global? : www.ristekdikti.go.id, https://www.quipper.com/id/blog/quipper-campus/campus-info/revolusi-industri-4-0/

Selanjutnya, Menteri Riset, Teknologi dan Pendidikan Tinggi (Menristekdikti) Mohamad Nasir mengatakan bahwa tantangan revolusi industri 4.0 harus direspon secara cepat dan tepat oleh seluruh pemangku kepentingan di lingkungan Kementerian, Riset, Teknologi dan Pendidikan Tinggi (Kemenristekdikti) agar mampu meningkatkan daya saing bangsa Indonesia di tengah persaingan global. Hal ini diungkapkan Menteri Nasir dalam pembukaan acara Rapat Kerja Nasional (Rakernas) Kementerian Riset, Teknologi, dan Pendidikan Tinggi (Kemenristekdikti) 2018 yang digelar di Kampus Universitas Sumatera Utara (USU), Medan(17/1/2018).

Menristekdikti menjelaskan ada lima elemen penting yang harus menjadi perhatian dan akan dilaksanakan oleh Kemenristekdikti untuk mendorong pertumbuhan ekonomi dan daya saing bangsa di era Revolusi Industri 4.0, yaitu:

1. Persiapan sistem pembelajaran yang lebih inovatif di perguruan tinggi seperti penyesuaian kurikulum pembelajaran, dan meningkatkan kemampuan mahasiswa dalam hal data Information Technology (IT), Operational Technology (OT), Internet of Things (IoT), dan Big Data Analitic, mengintegrasikan objek fisik, digital dan manusia untuk menghasilkan lulusan perguruan tinggi yang 
kompetitif dan terampil terutama dalam aspek data literacy, technological literacy and human literacy.

2. Rekonstruksi kebijakan kelembagaan pendidikan tinggi yang adaptif dan responsif terhadap revolusi industri 4.0 dalam mengembangkan transdisiplin ilmu dan program studi yang dibutuhkan. Selain itu, mulai diupayakannya program Cyber University, seperti sistem perkuliahan distance learning, sehingga mengurangi intensitas pertemuan dosen dan mahasiswa. Cyber University ini nantinya diharapkan menjadi solusi bagi anak bangsa di pelosok daerah untuk menjangkau pendidikan tinggi yang berkualitas.

3. Persiapan sumber daya manusia khususnya dosen dan peneliti serta perekayasa yang responsive, adaptif dan handal untuk menghadapi revolusi industri 4.0. Selain itu, peremajaan sarana prasarana dan pembangunan infrastruktur pendidikan, riset, dan inovasi juga perlu dilakukan untuk menopang kualitas pendidikan, riset, dan inovasi.

4. Terobosan dalam riset dan pengembangan yang mendukung Revolusi Industri 4.0 dan ekosistem riset dan pengembangan untuk meningkatkan kualitas dan kuantitas riset dan pengembangan di Perguruan Tinggi, Lembaga Litbang, LPNK, Industri, dan Masyarakat.

5. Terobosan inovasi dan perkuatan sistem inovasi untuk meningkatkan produktivitas industri dan meningkatkan perusahaan pemula berbasis teknologi. ristekdikti.go.id https:// www.kopertis6.or.id /component/content/article/49-dikti/4107-pengembangan-iptek-danpendidikan-tinggi-di-era-revolusi-industri-40.html

Revolusi industri 4.0 merupakan tantangan bagi perguruan tinggi. Sumberdaya manusia yang mengenyam pendidikan di perguruan tinggi harus memiliki kemampuan untuk menghadapi dan beradaptasi dengan perkembangan zaman. Salah satunya menguasai sistem informasi berbasis cyber. Hal ini disampaikan oleh Rektor Universitas Lampung (Unila) Prof. Dr. Ir. Hasriadi Mat Akin, M.P., saat membuka Simposium Persfektif Riset di Era Revolusi Industri 4.0 dengan tema "Sinergi dan Kontribusi Perguruan Tinggi dan Lembaga Riset Nonkementerian Terhadap Issue Strategis Daerah Lampung”, di ruang sidang utama lantai 2, Gedung Rektorat Unila, Jumat (21/12/2018).

Revolusi industri 4.0 mengambil berbagai bentuk misalnya digitalisasi kekuatan komputasi dan analitik data yang melahirkan teknologi "cyber physical" di dalam "autonomus vehicle" atau kendaraan tanpa awak, "three D printing" yang bisa membuat bangunan dan senjata, "advanced robotic" yang bisa mengambil alih peran manusia bahkan bisa menjadi 
pemandu wisata. Selanjutnya "internet of change", "big data", "artificial intelligence", "virtual reality", "block chain" hingga "crytpo currency" yaitu mata uang tanpa bank sentral.

Industri 4.0 adalah revolusi teknologi. Manusia menghadapi ketidakpastian karena berubah sangat cepat. Oleh karena itu, perguruan tinggi harus siap dengan menerapkan pembelajaran yang lebih inovatif pada kurikulum dan terampil pada digital literasy. Kemudian, mulai mengupayakan program cyber university yang memungkinkan terlaksananya pendidikan jarak jauh. Tantangan revolusi industri 4.0 dapat menjadi peluang untuk maju di masa depan jika perguruan tinggi mengedepankan inovasi. https://www.unila.ac.id/simposium-perspektif-risetdi-era-revolusi-industri-4-0/

Dalam beberapa tahun ke depan akan semakin banyak jenis pekerjaan yang berkurang dan muncul berbagai jenis pekerjaan baru, Menteri Ketenagakerjaan (Menaker) M. Hanif Dhakiri, seperti diberitakan dalam Liputan6.com, Kamis (28/6/2018), menyatakan bahwa beberapa jenis pekerjaan, seperti penjaga gerbang toll, kasir, penjaga toko, pekerja pabrik industri, manajer administrasi, mekanis, tukang cetak, pengantar surat, sopir, petugas ekspedisi, pekerja pabrik, operator, mesin jahit, perangkat komunikasi dan radio, resepsionis, tukang kayu, disain tiga dimensi, pengolah semikonduktor, travel agents, juru masak fast-food dan operator mesin, ahli las, staf akuntan, operator mesin, sopir truk dan ahli mesin dan masih banyak lagi jenis pekerjaan, mulai berkurang. Beberapa jenis pekerjaan baru muncul atau makin banyak diperlukan diantaranya programer komputer, operator komputer, analis koding, operator peralatan otomatis, pengemudi taxi dan motor on-line, analis keamanan komputer, trainer, perawat, manajer keuangan, pengacara, agen penjualan, analis, terapis fisiologis, penasihat keuangan, SDM, perawat, dokter, programer dan layanan berita reguler, dan lain lain. Sementara itu beberapa pekerjaan yang diperkirakan akan tumbuh antara lain pekerjaan terkait pemeliharaan dan instalasi, mediasi, medis, analis data, manajer sistem informasi, konselor vokasi, analis dampak lingkungan, perancang, pemrograman kecerdasan buatan, perancang dan pengendali mesin otomasi, perancang sofware dan game online.

Beberapa tantangan pada era industri 4.0 diidentifikasi sebagai berikut; 1) peningkatan keamanan teknologi informasi; 2) peningkatan keandalan dan stabilitas mesin produksi; 3) peningkatan keterampilan; 4) keengganan para pemangku kepentingan untuk berubah; dan 5) hilangnya banyak pekerjaan karena adanya otomatisasi (Sung, 2017, dalam Yahya, 2018). Oleh karenanya untuk menjawab tantangan tersebut, khususnya perguruan tinggi, harus pula berubah. 
Semua pemangku kepentingan di perguruan tinggi harus mau berubah. Dosen, tenaga kependidikan, dan mahasiswa harus berubah. Semua pihak harus berupaya meningkatkan kompetensi diri, terus belajar, dan menyesuaikan dengan kebutuhan era ini.

Pimpinan perguruan tinggi berkewajiban memberikan fasilitas yang dibutuhan untuk keperluan peningkatan kompetensi ini. Fasilitas fisik berupa peralatan canggih di laboratorium dan workshop harus diadakan, sementara fasilitas non fisik berupa pelatihan dan sertifikasi diupayakan bisa diselenggarakan baik secara mandiri maupun bekerjasama dengan pihak lain. Pimpinan perguruan tinggi harus pula memberikan jaminan bahwa lulusannya dapat terserap pasar kerja dengan waktu tunggu yang singkat. Survey kebutuhan pasar harus secara rutin dilakukan sehingga bisa digunakan sebagai data awal dalam menyusun kurikulum yang sesuai dengan kebutuhan pasar tersebut. Para dosen juga dituntut untuk terus mengikuti perkembangan teknologi dan pasar kerja sehingga materi pengajaran maupun metode pengajarannya selalu menyesuaikan dengan kebutuhan pasar tersebut.

Perkembangan kebutuhan pasar yang cepat harus diantisipasi perguruan tinggi dengan penyesuaian kurikulum. Jika dalam keadaan normal, kurikulum ditinjau dan diperbaharui setiap 5 tahun, namun di era ini waktu evaluasi perlu dipersingkat, misalkan setiap 2-3 tahun. Dengan demikian, kurikulum selalu mampu beradaptasi dengan kebutuhan pasar. Selain itu metode pembelajaran juga perlu disesuaikan. Pada era ini, para mahasiswanyapun merupakan mahasiswa yang biasa disebut sebagai Generasi Z, yang sangat beda dengan sikap dan kebiasaan generasi para dosennya. Pembelajaran cara digital, daring, dan melalui perangkat komputer perlu makin banyak disiapkan. Mahasiswa harus dapat akses kepada pelajaran tanpa kenal batas waktu dan tempat. https://www.its.ac.id /news/2018/11/04/35759/

Dunia tengah memasuki era revolusi industri 4.0 dan membutuhkan sumber daya manusia yang tidak hanya mengandalkan kemampuan teknis saja. "Dunia pendidikan sedang mengalami 'goncangan' menghadapi tantangan era revolusi industri 4.0," ujar Rektor Universitas Multimedia Nusantara ( UMN) Dr. Ninok Leksono MA dalam konferensi pers menyambut Hari Pendidikan Nasional di Newsroom UMN, Rabu (2/5/2018).

Tantangan pendidikan ke depan adalah bagaimana menyiapkan sumber daya manusia yang tidak akan tergantikan dengan mesin tersebut, tambahnya. Menghadapi tantangan tersebut, Wakil Rektor UMN Ir. Andrey Andoko menyampaikan pendidikan tinggi perlu mempersiapkan sumber daya yang memiliki kompetisi tersebut. "Saat ini pekerjaan yang bersifat rutin dan harian 
sudah banyak diambil alih mesin. Ke depan pekerjaan yang masih belum bisa diambil alih oleh mesin dan robot adalah pekerjaan yang membutuhkan kemampuan dalam melakukan analisa, $\begin{array}{llll}\text { mengambil } & \text { keputusan atau }\end{array}$ Andrey.(https://edukasi.kompas.com/read/2018/05/02/15561621/ki-hadjar-dewantara-danguncangan-pendidikan-era-industri-40_)

\section{Kesiapan Prodi Pendidikan Sejarah Menghadapi Revolusi Industri 4.0}

Ada baiknya kita mencermati pernyataan Menteri Ketenagakerjaan (Menaker) yang dirilis media tentang kesiapan bangsa ini menghadapi perubahan besar pada pola industri dan ekonomi global melalui Revolusi Industri 4.0 ini. Bayang-bayang industries shock dan empower shock semakin rentan menghantui kesiapan bangsa ini terhadap perubahan yang telah berjalan di hadapan mata. Menaker kembali menegaskan kepada media, bahwa perkembangan teknologi dan digitalisasi akan membuat sekitar 56 persen pekerja di dunia akan kehilangan pekerjaan dalam 10 sampai 20 tahun ke depan. Pernyataan Menaker tersebut juga selaras dengan proyeksi Organisasi Buruh Internasional (International Labour Organization/ILO) belum lama ini.

Jika dunia industri Indonesia tengah dihadapkan pada tantangan era generasi keempat (4.0), maka berbeda halnya dengan pendidikan di Indonesia yang saat ini masih bergelut dengan ragam tantangan di era generasi ketiganya (3.0). Kondisi ini ditandai dengan tuntutan akan peningkatan kualitas pembelajaran dan meninggalkan pola kebijakan lama yang sekadar berkutat pada masalah pemerataan akses serta pemenuhan sarana prasarana pendidikan. Perubahan pola kebijakan yang berorientasi pada kualitas pembelajaran ini selaras dengan tuntutan tentang apa dan bagaimana seharusnya pendidikan di Indonesia sebagai media penyiapan sumber daya manusia yang siap terlibat dalam tantangan Revolusi Industri 4.0 tersebut.

Bekaitan dengan hal tersebut, pertanyaan yang pasti muncul adalah, "Siapkah Prodi Pendidikan Sejarah memenuhi tuntutan sekaligus menghadapi tantangan revolusi industri 4.0?" Beberapa hal mengenai sampai di mana dan persiapan apa yang diperlukan, akan diuraikan di bawah ini.

\section{Kurikulum}

Kebijakan Kurikulum yang telah mengelaborasi kemampuan mahasiswa pada dimensi pedagogik, kecakapan hidup, kemampuan hidup bersama (kolaborasi), dan berpikir kritis dan kreatif, yaitu pengedepanan 'soft skills' dan 'transversal skills', keterampilan hidup, dan 
keterampilan yang secara kasat tidak terkait dengan bidang pekerjaan dan akademis tertentu. Namun, hal itu bermanfaat luas pada banyak situasi pekerjaan layaknya kemampuan berpikir kritis dan inovatif, keterampilan interpersonal, warga negara yang berwawasan global, dan literasi terhadap media dan informasi yang ada.

Banyak kajian mengemukakan bahwa implementasi kurikulum di lapangan mengalami degradasi yang keluar konteks dan tidak lagi berorientasi pada pencapaian kemampuan mahasiswa tersebut pada pemahaman ilmu dalam konteks praktik hidup dan keseharian, namun hanya berkisar pada target pencapaian kompetensi mahasiswa yang digambarkan pada nilai-nilai akademik semata. Oleh karena itu, jika biasanya, kurikulum ditinjau dan diperbaharui setiap 5 tahun, namun di era ini waktu evaluasi perlu dipersingkat, setiap 3 tahun. Dengan demikian, kurikulum selalu mampu beradaptasi dengan kebutuhan pasar.

Mata kuliah Kewirausahaan untuk Prodi Pendidikan Sejarah menjadi sangat penting dalam menghadapi revolusi industri 4.0 ini. Dengan tujuan, setelah mahasiswa lulus selain mahasiswa menjadi guru sejarah juga dapat berwirausaha sesuai dengan keahliannya.

\section{Metode Belajar}

Menstimulus kemampuan mahasiswa melalui beragam terobosan metode belajar kontekstual yang mendorong mahasiswa berpikir kritis dalam beragam konteks hidup yang nanti dihadapinya, seperti problem-based learning, inquiry-based learning, dan ragam pendekatan pembelajaran lainnya. Sehingga tidak sekadar berfokus pada pola-pola lama dan monoton pada pembelajaran yang minim kreativitas. Metode pembelajaran yang beragam dan membuka keleluasaan dosen dalam mengeksplorasi sistem dan pola pembelajaran yang dijalankan di kelas, diharapkan akan juga memperluas wawasan mahasiswa tentang kontekstualisasi ilmu yang didapatkannya di dalam kelas menuju praktik hidup yang dihadapinya nanti sebagai bagian dari realitas kehidupan.

Kecuali itu, persiapan sistem pembelajaran yang lebih inovatif di perguruan tinggi termasuk bagi Prodi Pendidikan Sejarah seperti penyesuaian kurikulum pembelajaran, dan meningkatkan kemampuan mahasiswa dalam hal data Information Technology (IT), Operational Technology (OT), Internet of Things (IoT), dan Big Data Analitic, mengintegrasikan objek fisik, digital dan manusia untuk menghasilkan lulusan perguruan tinggi yang kompetitif dan terampil terutama dalam aspek data literacy, technological literacy and human literacy mutlak diperlukan. 


\section{Penguasaan Data, Informasi, dan Teknologi}

Menstimulus dan memfasilitasi mahasiswa untuk menguasai data dan informasi secara global, serta teknologi informasi yang dielaborasi dengan menciptakan ruang-ruang kreativitas dan ragam peluang yang memberikan keuntungan ekonomi yang sifatnya luas. Dalam hal ini, perguruan tinggi khususnya Prodi Pendidikan Sejarah harus dapat mengakomodir infrastruktur digital yang dibutuhkan mahasiswa untuk meniscayakan penguasaan data, informasi, serta teknologi tersebut.

\section{Kapasitas yang Adaptif}

Mendorong dan menekankan kapasitas lulusan yang lincah, adaptif, dan sensitif terhadap perubahan lingkungan industri dan ekonomi. Keseimbangan pemahaman antara konsep pengetahuan dan keterampilan adalah hal yang penting, tetapi belum cukup bagi mahasiswa untuk dapat memahami cepatnya perubahan lingkungan. Survival of the fittest sepertinya akan berlaku di era generasi keempat ini. Hanya mereka yang adaptiflah, yang akan survive terhadap gempuran Revolusi Industri 4.0 ini.(https://kumparan.com/birokratmenulis/mengurai-pekerjaan-rumah-pendidikan-indonesia-menyongsong-revolusi-industri -4$\underline{0-1543639076398979922)}$

Revolusi Industri 4.0 merupakan perubahan strategis dan drastis tentang pola produksi yang mengolaborasikan tiga dimensi utama di dalamnya, yakni manusia, teknologi/mesin, dan big data. Dalam banyak literatur, kunci dari era industri generasi keempat ini bukan lagi berkisar pada ukuran atau besaran perusahaan atau organisasi, tetapi kelincahan dan sifat adaptif yang dimiliki untuk dapat bertahan dalam iklim kompetitif dan dinamis menghadapi perubahan yang bergerak melesat. Soft skills dan transversal skills menjadi modal penting bagi generasi yang hidup dan menjadi pelaku perubahan di era revolusi industri tersebut.

\section{Kesimpulan}

Perkembangan ilmu pengetahuan dan teknologi telah mengubah dunia sebagaimana revolusi industri generasi pertama melahirkan sejarah ketika tenaga manusia dan hewan digantikan oleh kemunculan mesin uap pada abad ke-18. Revolusi ini dicatat oleh sejarah berhasil mengangkat naik perekonomian secara dramatis. Distruptif teknologi Revolusi industri generasi keempat saat ini yang ditandai dengan kemunculan komputer super, kecerdasan buatan 
atau Intelegensi Artifisial. "Akan banyak pekerjaan hilang digantikan dengan robot atau kecerdasan buatan. Namun juga menjadi peluang karena banyak bidang pekerjaan baru yang muncul.

Kesuksesan sebuah negara dalam menghadapi revolusi industri 4.0 erat kaitannya dengan inovasi yang diciptakan oleh sumber daya yang berkualitas, sehingga Perguruan Tinggi dalam hal ini Prodi Pendidikan Sejarah wajib dapat menjawab tantangan untuk menghadapi kemajuan teknologi dan persaingan dunia kerja di era globalisasi. Dalam menciptakan sumber daya yang inovatif dan adaptif terhadap teknologi, diperlukan penyesuaian sarana dan prasarana pembelajaran dalam hal teknologi informasi, internet, analisis big data dan komputerisasi. Perguruan tinggi yang menyediakan infrastruktur pembelajaran tersebut diharapkan mampu menghasilkan lulusan yang terampil dalam aspek literasi data, literasi teknologi dan literasi manusia.

Oleh karenanya untuk menjawab tantangan tersebut, perguruan tinggi khususnya Prodi

Pendidikan Sejarah, harus pula berubah. Semua pemangku kepentingan, dosen, tenaga kependidikan, dan mahasiswa harus berubah. Semua pihak harus berupaya meningkatkan kompetensi diri, terus belajar, dan menyesuaikan dengan kebutuhan era ini. Prodi Pendidikan Sejarah harus siap dengan menerapkan pembelajaran yang lebih inovatif pada kurikulum dan terampil pada digital literasy. Para dosen dituntut untuk terus mengikuti perkembangan teknologi dan pasar kerja sehingga materi pengajaran maupun metode pengajarannya selalu menyesuaikan dengan kebutuhan pasar tersebut.

\section{DAFTAR PUSTAKA}

Diyan Nur Rakhmah, Mampukah Pendidikan Kita Beradaptasi dengan Revolusi Industri 4.0? https://kumparan.com/birokrat-menulis/mengurai-pekerjaan-rumah-pendidikanindonesia-menyongsong-revolusi-industri-4-0-1543639076398979922 (Diekses, 16-42019)

Era Revolusi Industri 4.0, Saatnya Generasi Millennial Menjadi Dosen Masa Depan http://sumberdaya.ristekdikti.go.id/index.php/2018/01/30/era-revolusi-industri-4-0saatnya-generasi-millennial-menjadi-dosen-masa-depan/

(Diakses, 14-4-2019) 
Mas Agus Mardyanto, Sikap Perguruan Tinggi pada Era Industri 4.0

https://www.its.ac.id/news/2018/11/04/35759/ (Diakeses, 15-4-2019)

Tantangan di Era Revolusi Industri 4.0 Bagi Perguruan Tinggi Indonesia

www.ristekdikti.go.id

https://www.quipper.com/id/blog/quipper-campus/campus-info/revolusi-industri-4-0/

(Diakses, 12-4-2019)

STAI-DDI, Metode Pendidikan Banu dalam BeradaptasidenganRevolusilndustri4.0, 2019

http://staiddisidrap.ac.id/blog/metode-pendidikan-baru-dalam-beradaptasi-dengan-

revolusi-industri-4-0/ (Diakses, 10-4-2019)

Yohanes Enggar Harususilo, “Ki Hadjar Dewantara dan 'Guncangan' Pendidikan Era Industri 4.0", https://edukasi.kompas.com/read/2018/05/02/15561621/ki-hadjar-dewantara-danguncangan-pendidikan-era-industri-40

https://edukasi.kompas.com/read/2018/05/02/15561621/ki-hadjar-dewantara-danguncangan-pendidikan-era-industri-40 (Diakses, 18-4-2019)

709 | Seminar Nasional Sejarah ke 4 Jurusan Pendidikan Sejarah Universitas Negeri Padang 